\title{
Does nature provide the clues for future heart failure treatments?
}

\author{
Teresa M. Lee, MD, MS
}

\footnotetext{
From the Division of Pediatric Cardiology, Department of Pediatrics, Columbia University Medical Center, New York, NY.

Disclosures: Author has nothing to disclose with regard to commercial support.

Received for publication Dec 27, 2017; accepted for publication Dec 28, 2017; available ahead of print Feb 2, 2018.

Address for reprints: Teresa M. Lee, MD, MS, Division of Pediatric Cardiology, Department of Pediatrics, Columbia University Medical Center, 3959 Broadway, BHN2, New York, NY 10032 (E-mail: t12164@ columbia.edu).

J Thorac Cardiovasc Surg 2018;155:2029

$0022-5223 / \$ 36.00$

Copyright (c) 2018 by The American Association for Thoracic Surgery

https://doi.org/10.1016/j.jtcvs.2017.12.101
}

Heart failure results in significant morbidity and mortality. Some developments that have advanced the field include better medications for symptom control, pharmacologic inotropic support, and mechanical devices for those with end-stage congestive heart failure. However, better disease understanding and treatments are still needed.

In their article, "Right ventricular involution: What can we learn from nature's model of compensated hypertrophy?" Bowen and colleagues ${ }^{1}$ examine the process of right ventricular involution. By studying mice right after birth, they describe some of the shifts that occur at the cellular and molecular level as the right ventricle shifts from a high-pressure chamber in fetal life to a low-pressure chamber after birth. They demonstrate differences in ventricular thickness and apoptosis. In particular, at the transcriptome level, there is increased expression of proapoptotic genes in the initial stages.

Apoptosis inhibitors are currently being studied for other diseases, such as in cancers and neurologic disorders. Other transcriptome changes have been implicated in those with cardiomyopathy. ${ }^{2}$ As well, recent literature demonstrates that the epigenome may play a role. ${ }^{3}$ Given recent advances in cellular modeling with induced pluripotent

\section{References} 107-20. $136: 1613-25$

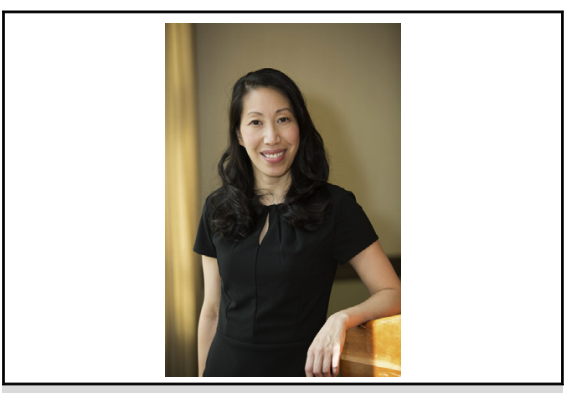

Teresa M. Lee, MD, MS

Central Message

The molecular process of right ventricular involution may help provide drug targets for future heart failure treatments.

See Article page 2024.

stem cell technology, it is foreseeable that the molecular understanding of heart failure will continue to grow. The insights gained from such studies can help direct research and drug development in the future.

1. Bowen ME, Liu X, Sundwall PM, Drakos SG, Li DY, Selzman CH, et al. Right ventricular involution: What can we learn from nature's model of compensated hypertrophy? J Thorac Cardiovasc Surg. 2018;155:2024-8.e1.

2. Haas J, Mester S, Lai A, Frese KS, Sedaghat-Hamedani F, Kayvanpour E, et al Genomic structural variations lead to dysregulation of important coding and non-coding RNA species in dilated cardiomyopathy. EMBO Mol Med. 2018;10:

3. Rosa-Garrido M, Chapski DJ, Schmitt AD, Kimball TH, Karbassi E, Monte E, et al. High-resolution mapping of chromatin conformation in cardiac myocytes reveals structural remodeling of the epigenome in heart failure. Circulation. 2017; 